\title{
Mechanisms of Growth Plate Maturation and Epiphyseal Fusion
}

\author{
Joyce Emons $^{a}$ Andrei S. Chagin ${ }^{c}$ Lars Sävendahl $^{c}$ Marcel Karperien $^{b}$ \\ Jan M. Wit ${ }^{\mathrm{a}}$ \\ ${ }^{a}$ Department of Paediatrics, Leiden University Medical Center, Leiden, and ${ }^{b}$ Department of Tissue Regeneration, \\ University of Twente, Enschede, The Netherlands; 'Department of Women's and Children's Health, Karolinska \\ Institutet, Stockholm, Sweden
}

\section{Key Words}

Epiphyseal fusion - Growth plate maturation •

Cartilage disorder $\cdot$ Growth disorder

\begin{abstract}
Longitudinal growth occurs within the long bones at the growth plate. During childhood, the growth plate matures, its total width decreases and eventually it disappears at the end of puberty with complete replacement by bone along with cessation of longitudinal growth. The exact mechanism of epiphyseal fusion is still not completely understood and experimental studies are complicated by the fact that there is a species difference between humans and rabbits that do fuse their growth plates and rodents that do not. This mini review summarizes hypotheses and theories postulated in the literature regarding growth plate maturation and epiphyseal fusion. Growth factors, local regulators and hormones involved in growth plate maturation are described as well as four postulated hypotheses and theories regarding the final steps in epiphyseal fusion: apoptosis, autophagy, transdifferentiation and hypoxia. A better insight into the mechanisms of epiphyseal fusion may ultimately help to develop new strategies for the treatment of cartilage and growth disorders.

Copyright $\odot 2011$ S. Karger AG, Basel
\end{abstract}

\section{Introduction}

Longitudinal growth occurs at the epiphyseal plate, a thin layer of cartilage entrapped between the epiphyseal and metaphyseal bone, at the distal ends of the long bones [1]. In the growth plate, immature cells lie toward the epiphysis, called the resting zone, with more mature chondrocytes in the proliferating zone and large chondrocytes in the hypertrophic zone adjacent to this. During childhood, the growth plate matures, its total width decreases and eventually it disappears at the end of puberty with complete replacement by bone along with cessation of longitudinal growth. In specific disorders, timing of epiphyseal fusion is advanced or delayed; for example, in patients with estrogen deficiency it is delayed and in patients with precocious puberty it is advanced [2].

Nonsurgical treatment options to increase or decrease adult height are restricted to the period before epiphyseal fusion occurs. Delaying and/or lengthening the period of epiphyseal fusion, with or without additional growthpromoting therapy, can result in an increase in adult height by allowing more time for growth-supporting treatments in short children, while promoting epiphyseal fusion may reduce adult height in extremely tall children. The exact mechanism of epiphyseal fusion is still not

\section{KARGER}

Fax +4161306 1234

E-Mail karger@karger.ch

www.karger.com
(C) 2011 S. Karger AG, Basel

$1663-2818 / 11 / 0756-0383 \$ 38.00 / 0$

Accessible online at:

www.karger.com/hrp
Jan M. Wit

Department of Paediatrics

Leiden University Medical Center

NL-2300 ZA Leiden (The Netherlands)

Tel. +31 71262 824, E-Mail j.m.wit@lumc.nl 


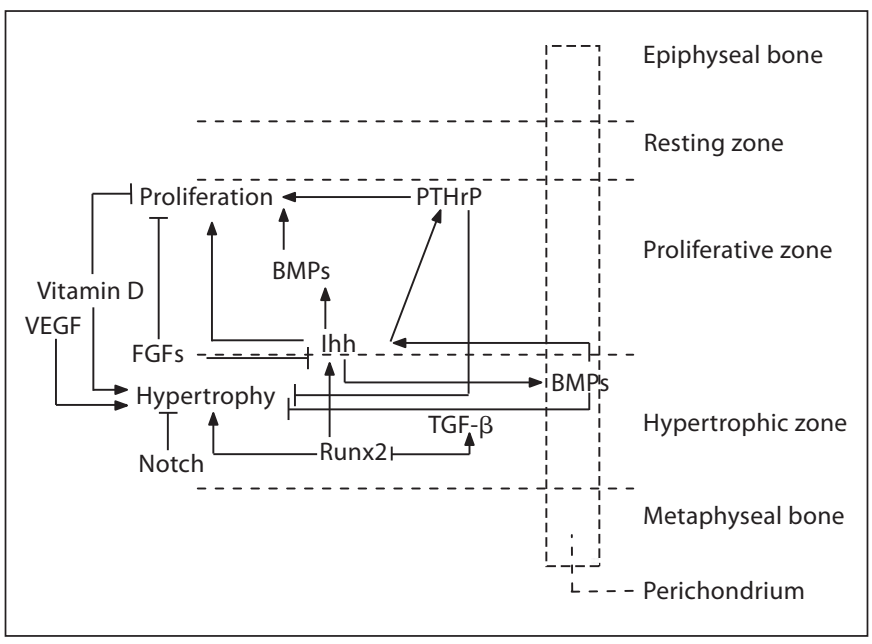

Fig. 1. Schematic picture of growth factors that play an important role in growth plate maturation.

completely understood. The fact that humans and rabbits fuse their growth plates but rodents do not complicates the interpretation of animal studies [3]. This mini review summarizes hypotheses and theories postulated in the literature regarding mechanisms of growth plate maturation and epiphyseal fusion.

\section{Growth Factors and Local Regulators Associated with Growth Plate Maturation and/or Epiphyseal Fusion}

Chondrocytes in the growth plate are influenced by various regulatory factors that together determine the rate of proliferation and maturation. These influences and interactions are depicted in figure 1 and described in this mini review. The formation of bone and cartilage begins with the migration of undifferentiated mesenchymal cells that differentiate into chondrocytes already in the embryonic stage of bone development. Postnatally bone development continues, with maturation of the growth plate influenced by multiple growth factors and hormones until late puberty when the growth plate fuses. We discuss some important growth factors, hormones and local regulators that all have an important role in growth plate regulation and thereby maturation. In addition, the adjacent perichondrium is also an important contributor to growth plate regulation. It contributes to osteoblast formation and invasion of blood vessels. Perichondrial cells send signals to chondrocytes via bone morphoge- netic proteins (BMPs), fibroblast growth factors (FGFs) and Wnt signaling, but vice versa also receive signals back from epiphyseal chondrocytes [1].

Paracrine regulators like parathyroid hormone-related protein (PTHrP) and Indian hedgehog (Ihh) are considered key factors in the regulation of the growth plate. These secreted growth factors coordinate endochondral ossification by regulating chondrocyte proliferation and differentiation as well as osteoblast differentiation $[4,5]$. Both factors have been identified in the postnatal human growth plate and have been postulated to play a role in growth plate fusion since the expression levels change in puberty $[6,7]$.

In humans, mutations in the Ihh gene can lead to growth disorders. For example, acrocapitofemoral dysplasia, which is characterized by disproportional short stature, brachydactyly with cone-shaped epiphysis and premature fusion of the growth plates, is caused by a homozygous mutation of Ihh [8]. Postnatal ablation of Ihh in inducible and conditional knockout mice results in loss of the columnar structure in the growth plate, formation of ectopic hypertrophic chondrocytes, and premature vascular invasion. This causes advancement of growth plate maturation and induces early fusion of the growth plate [9]. In mammals, there are homologous proteins to Ihh in the hedgehog family, i.e. Sonic hedgehog and Desert hedgehog. Sonic hedgehog is very important during early embryonic development for patterning of many systems including the axial skeleton [10]. Interestingly, overexpression of Sonic hedgehog in chondrocytes interferes with growth plate organization and abrogates chondrocyte hypertrophy [11].

Modulation of parathyroid hormone and PTHrP signaling in the growth plate of mice also leads to abrupt closure of the growth plate, associated with decreased chondrocyte proliferation, accelerated differentiation and cell death [12]. This is in line with observations in Blomstrand chondrodysplasia patients who have an inactivating mutation of the parathyroid hormone receptor resulting in chondrodysplasia with advanced bone maturation [13]. In contrast, patients with Jansen chondrodysplasia who have an activating mutation of the parathyroid hormone receptor show a delay in bone maturation and are extremely short. Many of these features are recapitulated in the Jansen mouse model. Remarkably these mice show growth plate fusion early in life, suggesting that premature fusion may contribute to the extremely short stature of Jansen patients [12].

The transcription factor Runx 2 plays an important role in the regulation of chondrocyte hypertrophy and 
associated changes in the extracellular matrix [14]. In vitro studies showed that the expression and activation of this transcription factor is in part regulated by $\mathrm{PTHrP}$ and Ihh [15]. In addition, Runx 2 interacts with TGF- $\beta$ signaling via Smads in order to control chondrocyte maturation [16]. TGF- $\beta$ is stimulatory in early stages of cartilage formation but in later stages it inhibits chondrocyte terminal differentiation and it has been hypothesized that it stabilizes the phenotype of the prehypertrophic chondrocyte [17].

A critical step in endochondral ossification is when blood vessels enter from the primary spongiosum, and osteoblasts invade from the bone marrow to lay down trabecular bone. Vascular endothelial growth factor (VEGF) is a potent mediator of angiogenesis and shown to be important in chondrocyte and osteoblast differentiation. Recently it was suggested that VEGF might play a role in growth plate fusion. Estrogen increases VEGF expression in rat growth plate chondrocytes in vivo and in vitro [18]. In addition, in pubertal human growth plate samples the expression of VEGF was upregulated with progression of puberty [18]. This suggests that VEGF might play an important role in estrogen-induced growth plate fusion. However, when in the adult mouse VEGF was specifically overexpressed in the growth plate, no fusion was observed [19].

Vitamin D deficiency in mammals leads to disturbances of the growth plate structure including increased width of the hypertrophic zone, decreased programmed cell death in hypertrophic chondrocytes, delayed invasion of blood vessels and bone cells, and lack of mineralization [20, 21]. Vitamin D metabolites (24,25-dihydroxyvitamin D) can be produced locally in the growth plate and these metabolites have been shown to stimulate differentiation and decrease proliferation of chondrocytes $[22,23]$. The vitamin $D$ receptor is expressed in the resting, proliferative and early hypertrophic zone of the rat growth plate [24]. By what mechanism vitamin $D$ and its metabolites have an effect on the growth plate is not precisely known, although one suggested mechanism is through Ihh and PTHrP [25].

Other suggested factors important in chondrocyte differentiation and thereby growth plate maturation are the BMPs that promote chondrocyte differentiation. BMPs are differentially expressed across the rat growth plate and perichondrium with BMP agonists primarily expressed in the hypertrophic zone and BMP antagonists in the resting and proliferative zones [26]. This pattern might suggest evidence for a substantial role for BMP signaling in chondrocyte differentiation and thereby also growth plate

Mechanisms of Growth Plate Maturation and Epiphyseal Fusion maturation. Mice with a mutation in the BMP signaling pathway show deformities in bone, limb and digit development [27]. Minina et al. [28] published evidence for an interaction between BMP signaling and the Ihh-PTHrP feedback loop in the mouse. Ihh induces the expression of various BMPs and proliferating chondrocytes react to BMP signals with the upregulation of Ihh expression.

Another important pathway in chondrocyte development is the Wnt signaling pathway. Wnt signaling is involved in all stages of chondrocyte development since activation of the canonical Wnt pathway with $\beta$-catenin prevents differentiation of progenitor cells into chondrocytes and instead induces formation of osteoblasts [29]. In chondrocytes of the growth plate, canonical Wnt signaling stimulates hypertrophic chondrocyte differentiation. From in vitro studies it has been hypothesized that an alternative route of Wnt signaling through calciumdependent kinases is predominant in chondrocyte differentiation [29].

An evolutionarily conserved pathway downstream of many developmental processes is Notch signaling, which has also shown to be important in cartilage development. Notch signaling suppresses chondrocyte hypertrophy [30]. For example, Delta-Notch2 signaling that occurs downstream of the Ihh, BMP and PTHrP pathways inhibits the differentiation of prehypertrophic to hypertrophic chondrocytes. Overexpression of these pathways results in stunted limbs with reduced ossification in the chicken [30].

Finally, the group of FGFs can act as antagonists of $\mathrm{BMP}$ signaling and negatively regulate Ihh expression as shown in mice [31]. FGF signaling inhibits chondrocyte proliferation. Temporal changes in FGF and FGF receptor expression were found in the growth plate of rats and it was speculated that this might contribute to growth plate senescence and thereby longitudinal growth [32]. Activating mutations in one of the receptors for FGF (FGFR3) result in achondroplasia or hypochondroplasia, and in delayed growth plate maturation early in human life which normalizes in adolescence [33, 34]. Loss-offunction mutations of the FGFR3 gene result in tall stature in humans [35].

\section{Hormones Involved in Growth Plate Maturation and Epiphyseal Fusion}

Longitudinal bone growth is not only influenced by a variety of growth factors, but also by various hormones acting directly or indirectly on the growth plate. Estro- 
gens are known to play a key role in longitudinal bone growth by stimulating growth plate maturation, epiphyseal fusion and bone mineral accrual. Premature estrogen exposure in, for example, precocious puberty accelerates skeletal maturation, whereas on the contrary hypogonadism results in delay in skeletal maturation [36, 37]. Smith et al. [38] in 1994 described a male with an inactivating mutation in the estrogen receptor alpha $(\mathrm{ER} \alpha)$ that showed no pubertal growth spurt and continued growth into adulthood associated with absence of growth plate fusion, resulting in tall stature $(210 \mathrm{~cm})$ and osteoporosis suggesting a role for ER $\alpha$ in growth plate fusion. To determine the role of $\mathrm{ER} \alpha$ in grow th plate cartilage for skeletal growth, a mouse model with cartilage-specific inactivation of $\mathrm{ER} \alpha$ was recently developed [39]. Using these animals, it was found that $\mathrm{ER} \alpha$ in growth plate cartilage is not important for skeletal growth during early sexual maturation. In contrast, it is essential for high-dose $17 \beta$ estradiol to reduce the growth plate height in adult mice and for reduction of longitudinal bone growth in elderly mice. Any functional role of ER $\beta$ has not yet been defined in the human growth plate. Interestingly, the membranous G-protein-coupled estrogen receptor 30 has been found to be widely expressed in the human growth plate and, moreover, to decline during the progression of puberty [40]. Furthermore, in genetically manipulated female mice G-protein-coupled estrogen receptor 30 was recently found to be involved in mediating estrogen effects on bone growth [41]. Altogether these findings suggest that G-protein-coupled estrogen receptor 30 may play a role in mediating estrogen effects in the growth plate.

Sex steroids acting on the growth plate are mainly produced by the gonads, which secrete sex steroids into the circulation in a classical endocrine way. In addition to this endocrine route, estrogens can also be produced locally by aromatase in the growth plate ('intracrinology') [42]. Also other enzymes essential for estrogen production, including $17 \beta$-hydroxysteroid dehydrogenase, steroid sulfatase and type $15 \alpha$-reductase, have been detected in epiphyseal chondrocytes and shown to be upregulated during sexual maturation in the rat growth plate suggesting a role for these enzymes and the steroids they produce during pubertal growth and growth plate maturation [43].

Androgens can stimulate longitudinal bone growth also without conversion to estrogenic compounds [44]. This growth-increasing effect is not associated with increased circulating growth hormone $(\mathrm{GH})$ or insulinlike growth factor 1 (IGF-1), but might be a direct effect since androgen receptors are expressed in the human growth plate [45] and local administration of testosterone can increase unilateral tibial epiphyseal growth plate width in the rat [46]. Another route of action is that the androgenic effect is mediated by local IGF-1 expression $[47,48]$.

The mechanism by which estrogens and other hormones exert their effect on longitudinal growth and finally growth plate fusion is not fully understood. Besides direct effects on estrogen receptors in the growth plate, indirect estrogenic effects through other hormones like IGF-1, GH and PTHrP have also been proposed [49-51], since levels of IGF-1 and GH change in line with estrogen during puberty [52]. It is well known that GH and IGF-1 can increase growth velocity as well as accelerate bone maturation measured as a decrease in growth plate height in children [53, 54]. GH receptors and the IGF-1 receptor IGF1R are expressed on human growth plate chondrocytes [55]. The exact contributions of these hormones in growth plate maturation and epiphyseal fusion still need to be clarified.

\section{Senescence}

Senescence is a term for the structural and functional changes over time in the growth plate, such as a gradual decline in the overall growth plate height, proliferative zone height, hypertrophic zone height, size of hypertrophic chondrocytes and column density [56]. Growth plate transplantation experiments in rabbits showed that the growth rate of a transplanted growth plate depends on the age of the donor and not on the age of the recipient, suggesting that growth velocity is regulated by a local mechanism intrinsic to the growth plate [57]. With progression of puberty, senescence in the growth plate increases and it is believed that when senescence has progressed to a certain point the growth plate fuses. Recent evidence from rabbit studies indicates that senescence might occur because stem-like cells in the resting zone have a finite proliferative capacity, which is gradually exhausted [58]. A new hypothesis is that proliferation is influenced by a multiorgan genetic program and that proliferation declines when this genetic program has reached a critical point [59]. While authors of this study believe that growth of organs like the liver and kidney of mammals can be explained by this theory, the hypothesis was not tested in the growth plate.

Estrogen is thought to advance growth plate senescence, causing earlier proliferative exhaustion, and thus 
earlier fusion [56]. This might explain why estrogen treatment in girls does not induce growth plate fusion rapidly, but must act for years before fusion occurs. In line with this observation, the period of estrogen treatment required for growth plate fusion is longer in younger patients (e.g. in cases of precocious puberty) and shorter in older patients, like for example adults with a deficiency in aromatase compared to normal individuals [60].

\section{Growth Plate Maturation and Epiphyseal Fusion at the Cellular Level}

While there is no doubt that hormones and growth factors play a role in epiphyseal fusion, the final step at the cellular level is not completely understood. There are 4 mechanisms described in the literature which we would like to discuss in this review: apoptosis, autophagy, hypoxia and transdifferentiation.

\section{Apoptosis}

A most widely held hypothesis is that at the chondroosseous junction site of the growth plate, terminally hypertrophic chondrocytes die by undergoing apoptosis leaving behind a scaffold of cartilage matrix for osteoblasts that invade and lay down bone [61]. It is assumed that the same mechanism eventually also results in epiphyseal fusion. Studies in the rat showed that apoptosis-regulating proteins (the so-called caspases, which are cysteine proteases) are expressed in the growth plate and that there is an increased expression of proapoptotic factors with age [62]. Typical morphological changes when cells undergo apoptosis include cell shrinkage with intact organelles and integrity of membranes, pyknotic nuclei by aggregation of chromatin, fragmented DNA, partitioning of the cytoplasm and nucleus into membrane-bound vesicles (apoptotic bodies) and absence of an inflammatory response $[63,64]$. Interestingly, several recent studies failed to demonstrate a typical apoptotic appearance in the terminal hypertrophic chondrocytes and, therefore, these studies have questioned whether apoptosis is the final mechanism through which chondrocytes die in the terminal hypertrophic zone $[63,65]$. Furthermore, we recently analyzed a unique piece of fusing human growth plate tissue during epiphyseal fusion and were not able to find signs of classical apoptosis [66].

\section{Autophagy}

Roach and Clarke $[67,68]$ studied rabbit growth plates and described chondrocytes with condensed chromatin, suggestive of apoptosis, but the 'morphology of the cytosol' was unlike that of necrotic, apoptotic, or normal cells. In 2004, these authors came up with the term chondroptosis to describe the appearance of these cells [69]. They reported autophagic vacuoles in the chondroptotic cells, suggesting a role for autophagy in the process of cell death of the terminal hypertrophic cell. Autophagic cell death is a different form of programmed cell death that involves a catabolic process in which the cell degrades its own components through autophagosomes. Signs of autophagy (like condensed chromatin, double-membraned structures and autophagosomes) were also observed in avian hypertrophic chondrocytes and in chondrocytes of newborn mice [70, 71]. Roach et al. [72] reported autophagic vacuoles in terminal hypertrophic cells suggesting a role for autophagy in the final step of endochondral ossification. However, no autophagosomes or signs of autophagy have ever been described in the human growth plate.

\section{Transdifferentiation}

The oldest hypothesis is that at the chondro-osseous junction site of the growth plate terminal hypertrophic chondrocytes can transdifferentiate into osteoblasts [73]. This theory is based on mostly organ and cell culture models, like for example chondrocytes in mice and murine metatarsal bone cultures that were able to transdifferentiate into osteoblasts producing bone matrix [74]. Adams and Shapiro [75] discussed that evidence in support of transdifferentiation is mostly circumstantial. It is based on microscopic examination of chondrocyte and osteoblast populations at the chondro-osseous junction and results from different studies are inconsistent. Although direct evidence is lacking, others speculate that transdifferentiation is present at the chondro-osseous junction because terminally differentiated cells are producing collagen type 1 together with extracellular matrix factors [76]. In addition, to our knowledge human studies on transdifferentiation at the chondro-osseous junction in the growth plate have not been described.

\section{Hypoxia}

In a unique human growth plate tissue specimen in the process of undergoing epiphyseal fusion, we observed a dense border of thick bone surrounding growth plate remnants at the site where normally the growth plate is located (fig. 2). In addition, signs of hypoxia and early necrosis were found [66]. We postulated that the border of dense bone might function as a physical barrier for 


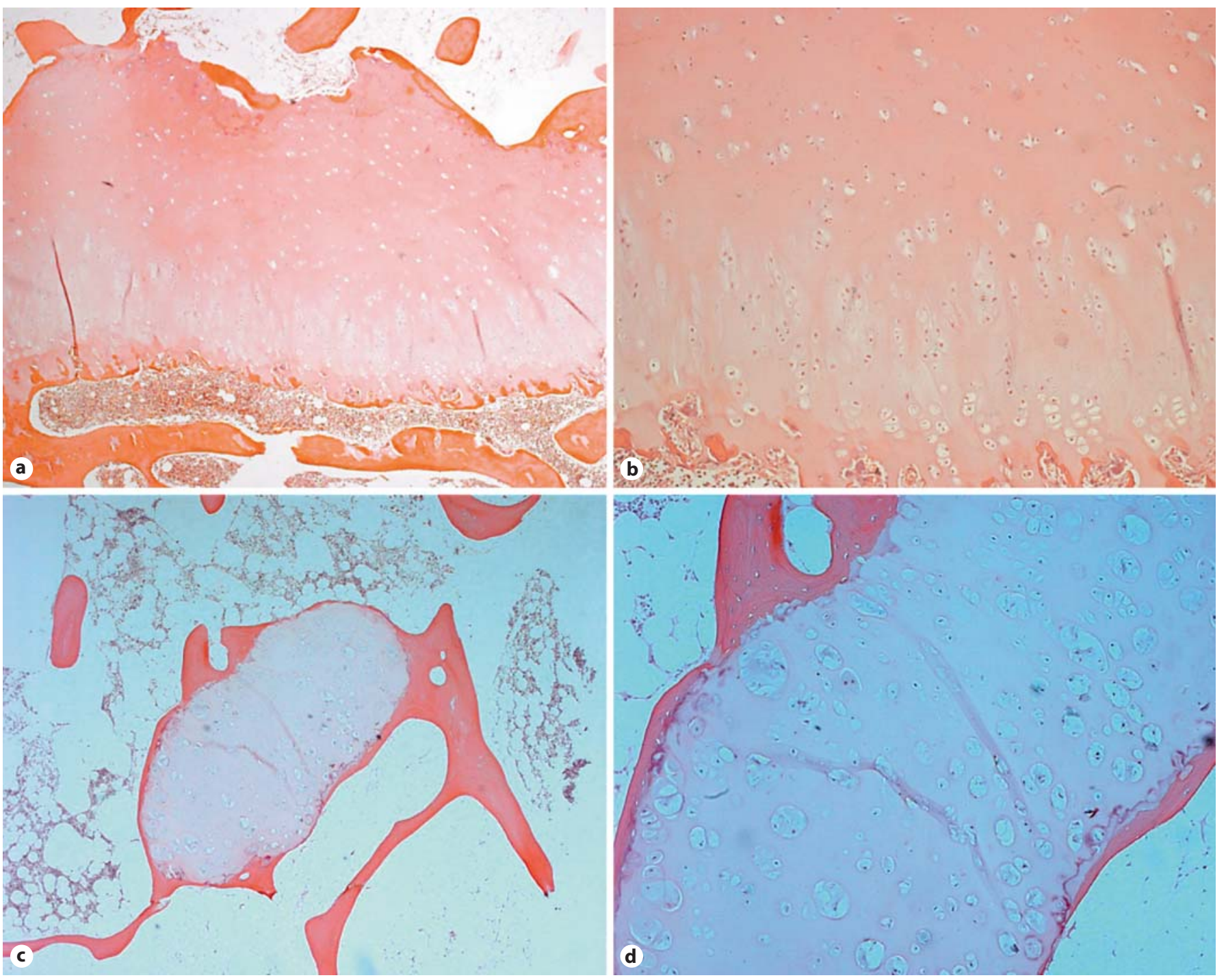

Fig. 2. Hematoxylin and eosin staining of sectioned human growth plates. In early pubertal patients, growth plate chondrocytes were organized in parallel columns. $\mathbf{a} \times 40$ magnification. $\mathbf{b} \times 100$ magnification. In a late pubertal patient, the growth plate was diminished to a small remnant surrounded by dense cortical-like bone. c $\times 40$ magnification. $\mathbf{d} \times 100$ magnification. Reproduced from Emons et al. [66], with permission.

oxygen and nutrients to reach the fusing growth plate resulting in hypoxia and eventually cell death in a nonclassical apoptotic way through necrosis or a mixture of apoptosis and necrosis. In line with this new hypothesis, White et al. [77] recently demonstrated bridging bone in the center of a distal human tibial growth plate obtained from a 12.9-year-old girl, which might be an early sign of this shelling process. Signs of a hypoxia-related process were also reported by Stewart et al. [78] who observed an upregulated expression of hypoxia-inducible factor $2 \alpha$
mRNA during chick and murine chondrocyte differentiation in vitro. Hypoxia-inducible factor $2 \alpha$ knockout mice are small, which might indicate that this gene has an important role in the growth plate and subsequently in the regulation of longitudinal growth [79]. Thus, epiphyseal fusion might be a hypoxia-related process leading eventually to cell death of growth plate chondrocytes. 


\section{Conclusion}

The exact mechanism by which physiological epiphyseal fusion occurs in humans is still not yet completely understood. Most of our knowledge regarding the regulation of growth plate fusion is based on animal studies. However, most animal models only partially correspond to the human situation and rodents do not fuse their growth plates at the end of puberty in normal physiological situations. More studies and better models are needed to reveal the mechanisms involved in epiphyseal fusion. Ultimately, this may help to develop new strategies for the treatment of cartilage and growth disorders.

\section{References}

$\checkmark 1$ Kronenberg HM: Developmental regulation of the growth plate. Nature 2003;423:332336.

-2 Carel JC, Eugster EA, Rogol A, Ghizzoni L, Palmert MR, Antoniazzi F, Berenbaum S, Bourguignon JP, Chrousos GP, Coste J, Deal S, de Vries L, Foster C, Heger S, Holland J, Jahnukainen K, Juul A, Kaplowitz P, Lahlou N, Lee MM, Lee P, Merke DP, Neely EK, Oostdijk W, Phillip M, Rosenfield RL, Shulman D, Styne D, Tauber M, Wit JM: Consensus statement on the use of gonadotropinreleasing hormone analogs in children. Pediatrics 2009;123:e752-e762.

3 van der Eerden BC, Gevers EF, Lowik CW, Karperien M, Wit JM: Expression of estrogen receptor alpha and beta in the epiphyseal plate of the rat. Bone 2002;30:478-485.

-4 Karp SJ, Schipani E, St-Jacques B, Hunzelman J, Kronenberg H, McMahon AP: Indian hedgehog coordinates endochondral bone growth and morphogenesis via parathyroid hormone related-protein-dependent and -independent pathways. Development 2000; 127:543-548.

5 van der Eerden BC, Karperien M, Gevers EF, Lowik CW, Wit JM: Expression of Indian hedgehog, parathyroid hormone-related protein, and their receptors in the postnatal growth plate of the rat: evidence for a locally acting growth restraining feedback loop after birth. J Bone Miner Res 2000;15:10451055.

6 Kindblom JM, Nilsson O, Hurme T, Ohlsson C, Savendahl L: Expression and localization of Indian hedgehog (Ihh) and parathyroid hormone related protein (PTHrP) in the human growth plate during pubertal development. J Endocrinol 2002;174:R1-R6.

-7 Hirai T, Chagin AS, Kobayashi T, Mackem S, Kronenberg HM: Parathyroid hormone/ parathyroid hormone-related protein receptor signaling is required for maintenance of the growth plate in postnatal life. Proc Natl Acad Sci USA 2011;108:191-196.

8 Hellemans J, Coucke PJ, Giedion A, De Paepe A, Kramer P, Beemer F, Mortier GR: Homozygous mutations in IHH cause acrocapitofemoral dysplasia, an autosomal recessive disorder with cone-shaped epiphyses in hands and hips. Am J Hum Genet 2003;72: 1040-1046.
-9 Maeda Y, Nakamura E, Nguyen MT, Suva LJ, Swain FL, Razzaque MS, Mackem S, Lanske B: Indian hedgehog produced by postnatal chondrocytes is essential for maintaining a growth plate and trabecular bone. Proc Natl Acad Sci USA 2007;104:6382-6387.

10 Chiang C, Litingtung Y, Lee E, Young KE, Corden JL, Westphal H, Beachy PA: Cyclopia and defective axial patterning in mice lacking Sonic hedgehog gene function. Nature 1996;383:407-413.

-11 Tavella S, Biticchi R, Schito A, Minina E, Di Martino D, Pagano A, Vortkamp A, Horton WA, Cancedda R, Garofalo S: Targeted expression of SHH affects chondrocyte differentiation, growth plate organization, and Sox9 expression. J Bone Miner Res 2004;19: 1678-1688.

12 Schipani E, Lanske B, Hunzelman J, Luz A, Kovacs CS, Lee K, Pirro A, Kronenberg HM, Juppner H: Targeted expression of constitutively active receptors for parathyroid hormone and parathyroid hormone-related peptide delays endochondral bone formation and rescues mice that lack parathyroid hormone-related peptide. Proc Natl Acad Sci USA 1997;94:13689-13694.

13 Jobert AS, Zhang P, Couvineau A, Bonaventure J, Roume J, Le Merrer M, Silve C: Absence of functional receptors for parathyroid hormone and parathyroid hormone-related peptide in Blomstrand chondrodysplasia. J Clin Invest 1998;102:34-40.

14 Yoshida CA, Komori T: Role of Runx proteins in chondrogenesis. Crit Rev Eukaryot Gene Expr 2005;15:243-254.

15 Yoshida CA, Yamamoto H, Fujita T, Furuichi $\mathrm{T}$, Ito $\mathrm{K}$, Inoue $\mathrm{K}$, Yamana $\mathrm{K}$, Zanma $\mathrm{A}, \mathrm{Ta}$ kada K, Ito Y, Komori T: Runx2 and Runx3 are essential for chondrocyte maturation, and Runx2 regulates limb growth through induction of Indian hedgehog. Genes Dev 2004; 18:952-963.

16 Leboy P, Grasso-Knight G, D’Angelo M, Volk SW, Lian JV, Drissi H, Stein GS, Adams SL: Smad-Runx interactions during chondrocyte maturation. J Bone Joint Surg Am 2001;83-A(suppl 1):S15-S22.
17 Ballock RT, Heydemann A, Wakefield LM, Flanders KC, Roberts AB, Sporn MB: TGFbeta 1 prevents hypertrophy of epiphyseal chondrocytes: regulation of gene expression for cartilage matrix proteins and metalloproteases. Dev Biol 1993;158:414-429.

18 Emons J, Chagin AS, Malmlof T, Lekman M, Tivesten A, Ohlsson C, Wit JM, Karperien M, Savendahl L: Expression of vascular endothelial growth factor in the growth plate is stimulated by estradiol and increases during pubertal development. J Endocrinol 2010; 205:61-68.

19 Maes C, Goossens S, Bartunkova S, Drogat B, Coenegrachts L, Stockmans I, Moermans K, Nyabi O, Haigh K, Naessens M, Haenebalcke L, Tuckermann JP, Tjwa M, Carmeliet P, Mandic V, David JP, Behrens A, Nagy A, Carmeliet G, Haigh JJ: Increased skeletal VEGF enhances beta-catenin activity and results in excessively ossified bones. EMBO J 2010;29:424-441.

20 Dean DD, Boyan BD, Schwart Z, Muniz OE, Carreno MR, Maeda S, Howell DS: Effect of 1alpha,25-dihydroxyvitamin $\mathrm{D}_{3}$ and 24R,25-dihydroxyvitamin $\mathrm{D}_{3}$ on metalloproteinase activity and cell maturation in growth plate cartilage in vivo. Endocrine 2001:14:311-323.

21 Donohue MM, Demay MB: Rickets in VDR null mice is secondary to decreased apoptosis of hypertrophic chondrocytes. Endocrinology 2002;143:3691-3694.

22 Boyan BD, Sylvia VL, Dean DD, Del Toro F, Schwartz Z: Differential regulation of growth plate chondrocytes by 1alpha,25$(\mathrm{OH}) 2 \mathrm{D} 3$ and $24 \mathrm{R}, 25-(\mathrm{OH}) 2 \mathrm{D} 3$ involves cell-maturation-specific membrane-receptor-activated phospholipid metabolism. Crit Rev Oral Biol Med 2002;13:143-154.

23 Schwartz Z, Pedrozo HA, Sylvia VL, Gomez $\mathrm{R}$, Dean DD, Boyan BD: 1alpha, 25- $(\mathrm{OH}) 2 \mathrm{D} 3$ regulates 25-hydroxyvitamin $\mathrm{D}_{3}$ 24R-hydroxylase activity in growth zone costochondral growth plate chondrocytes via protein kinase C. Calcif Tissue Int 2001;69:365372.

24 Hugel U, Weber L, Reichrath J, Mehls O, Klaus G: Rat growth plate chondrocytes express low levels of 25-hydroxy-1alpha-hydroxylase. J Steroid Biochem Mol Biol 2004; 89-90:143-147. 
25 Klaus G, von EB, May T, Hugel U, Mayer H, Ritz E, Mehls O: Synergistic effects of parathyroid hormone and 1,25-dihydroxyvitamin $\mathrm{D}_{3}$ on proliferation and vitamin $\mathrm{D}$ receptor expression of rat growth cartilage cells. Endocrinology 1994;135:1307-1315.

-26 Nilsson O, Parker EA, Hegde A, Chau M, Barnes KM, Baron J: Gradients in bone morphogenetic protein-related gene expression across the growth plate. J Endocrinol 2007; 193:75-84.

27 Pizette S, Niswander L: BMPs are required at two steps of limb chondrogenesis: formation of prechondrogenic condensations and their differentiation into chondrocytes. Dev Biol 2000;219:237-249.

-28 Minina E, Wenzel HM, Kreschel C, Karp S, Gaffield W, McMahon AP, Vortkamp A: $\mathrm{BMP}$ and Ihh/PTHrP signaling interact to coordinate chondrocyte proliferation and differentiation. Development 2001;128: 4523-4534.

29 Yates KE, Shortkroff S, Reish RG: Wnt influence on chondrocyte differentiation and cartilage function. DNA Cell Biol 2005;24:446457.

-30 Crowe R, Zikherman J, Niswander L: Delta-1 negatively regulates the transition from prehypertrophic to hypertrophic chondrocytes during cartilage formation. Development 1999;126:987-998.

- 31 Minina E, Kreschel C, Naski MC, Ornitz DM, Vortkamp A: Interaction of FGF, Ihh/ Pthlh, and BMP signaling integrates chondrocyte proliferation and hypertrophic differentiation. Dev Cell 2002;3:439-449.

- 32 Lazarus JE, Hegde A, Andrade AC, Nilsson $\mathrm{O}$, Baron J: Fibroblast growth factor expression in the postnatal growth plate. Bone 2007;40:577-586.

-33 Shiang R, Thompson LM, Zhu YZ, Church DM, Fielder TJ, Bocian M, Winokur ST, Wasmuth JJ: Mutations in the transmembrane domain of FGFR3 cause the most common genetic form of dwarfism, achondroplasia. Cell 1994;78:335-342.

- 34 Pannier S, Mugniery E, Jonquoy A, BenoistLasselin C, Odent T, Jais JP, Munnich A, Legeai-Mallet L: Delayed bone age due to a dual effect of FGFR3 mutation in Achondroplasia. Bone 2010;47:905-915.

- 35 Toydemir RM, Brassington AE, Bayrak-Toydemir P, Krakowiak PA, Jorde LB, Whitby FG, Longo N, Viskochil DH, Carey JC, Bamshad MJ: A novel mutation in FGFR3 causes camptodactyly, tall stature, and hearing loss (CATSHL) syndrome. Am J Hum Genet 2006;79:935-941.

- 36 Carel JC, Lahlou N, Roger M, Chaussain JL: Precocious puberty and statural growth. Hum Reprod Update 2004;10:135-147.

- 37 Sedlmeyer IL, Palmert MR: Delayed puberty: analysis of a large case series from an academic center. J Clin Endocrinol Metab 2002; 87:1613-1620.
8 Smith EP, Boyd J, Frank GR, Takahashi H, Cohen RM, Specker B, Williams TC, Lubahn DB, Korach KS: Estrogen resistance caused by a mutation in the estrogen-receptor gene in a man. N Engl J Med 1994;331:1056-1061.

-39 Borjesson AE, Lagerquist MK, Liu C, Shao R, Windahl SH, Karlsson C, Sjogren K, Movérare-Skrtic S, Antal MC, Krust A, Mohan S, Chambon P, Savendahl L, Ohlsson C: The role of estrogen receptor alpha in growth plate cartilage for longitudinal bone growth. J Bone Miner Res 2010;25:2414-2424.

40 Chagin AS, Savendahl L: GPR30 estrogen receptor expression in the growth plate declines as puberty progresses. J Clin Endocrinol Metab 2007;92:4873-4877.

41 Windahl SH, Andersson N, Chagin AS, Martensson UE, Carlsten H, Olde B, Swanson C, Movérare-Skrtic S, Savendahl L, Lagerquist MK, Leeb-Lundberg LM, Ohlsson $\mathrm{C}$ : The role of the $\mathrm{G}$ protein-coupled receptor GPR30 in the effects of estrogen in ovariectomized mice. Am J Physiol Endocrinol Metab 2009;296:E490-E496.

$42 \mathrm{Oz}$ OK, Millsaps R, Welch R, Birch J, Zerwekh JE: Expression of aromatase in the human growth plate. J Mol Endocrinol 2001;27: 249-253.

43 van der Eerden BC, Lowik CW, Wit JM, Karperien M: Expression of estrogen receptors and enzymes involved in sex steroid metabolism in the rat tibia during sexual maturation. J Endocrinol 2004;180:457-467.

44 Jansson JO, Eden S, Isaksson O: Sites of action of testosterone and estradiol on longitudinal bone growth. Am J Physiol 1983; 244:E135-E140.

-45 Nilsson O, Chrysis D, Pajulo O, Boman A, Holst M, Rubinstein J, Martin RE, Savendahl L: Localization of estrogen receptors-alpha and -beta and androgen receptor in the human growth plate at different pubertal stages. J Endocrinol 2003;177:319-326.

46 Ren SG, Malozowski S, Sanchez P, Sweet DE, Loriaux DL, Cassorla F: Direct administration of testosterone increases rat tibial epiphyseal growth plate width. Acta Endocrinol (Copenh) 1989;121:401-405.

47 Keenan BS, Richards GE, Ponder SW, Dallas JS, Nagamani M, Smith ER: Androgen-stimulated pubertal growth: the effects of testosterone and dihydrotestosterone on growth hormone and insulin-like growth factor-I in the treatment of short stature and delayed puberty. J Clin Endocrinol Metab 1993;76: 996-1001.

48 Maor G, Segev Y, Phillip M: Testosterone stimulates insulin-like growth factor-I and insulin-like growth factor-I-receptor gene expression in the mandibular condyle - a model of endochondral ossification. Endocrinology 1999;140:1901-1910.
49 Coutant R, de Casson FB, Rouleau S, Douay O, Mathieu E, Gatelais F, Bouhours-Nouet N, Voinot C, Audran M, Limal JM: Divergent effect of endogenous and exogenous sex steroids on the insulin-like growth factor I response to growth hormone in short normal adolescents. J Clin Endocrinol Metab 2004; 89:6185-6192.

50 Paspaliaris V, Petersen DN, Thiede MA: Steroid regulation of parathyroid hormone-related protein expression and action in the rat uterus. J Steroid Biochem Mol Biol 1995;53: 259-265.

51 Veldhuis JD, Keenan DM, Bailey JN, Adeniji A, Miles JM, Paulo R, Cosma M, SoaresWelch C: Estradiol supplementation in postmenopausal women attenuates suppression of pulsatile growth hormone secretion by recombinant human insulin-like growth factor type I. J Clin Endocrinol Metab 2008;93: 4471-4478.

52 Perry RJ, Farquharson C, Ahmed SF: The role of sex steroids in controlling pubertal growth. Clin Endocrinol (Oxf) 2008;68:415.

53 de Zegher F, Butenandt O, Chatelain P, Albertsson-Wikland K, Jonsson B, Lofstrom A Chaussain JL: Growth hormone treatment of short children born small for gestational age: reappraisal of the rate of bone maturation over 2 years and metanalysis of height gain over 4 years. Acta Paediatr Suppl 1997;423: 207-212.

-54 Kamp GA, Waelkens JJ, de Muinck KeizerSchrama SM, Delemarre-van de Waal HA, Verhoeven-Wind L, Zwinderman AH, Wit JM: High dose growth hormone treatment induces acceleration of skeletal maturation and an earlier onset of puberty in children with idiopathic short stature. Arch Dis Child 2002;87:215-220.

55 Werther GA, Haynes K, Edmonson S, Oakes S, Buchanan CJ, Herington AC, Waters MJ: Identification of growth hormone receptors on human growth plate chondrocytes. Acta Paediatr Suppl 1993;82(suppl 391):50-53.

56 Weise M, De Levi S, Barnes KM, Gafni RI, Abad V, Baron J: Effects of estrogen on growth plate senescence and epiphyseal fusion. Proc Natl Acad Sci USA 2001;98:68716876.

57 Stevens DG, Boyer MI, Bowen CV: Transplantation of epiphyseal plate allografts between animals of different ages. J Pediatr Orthop 1999; 19:398-403.

- 58 Schrier L, Ferns SP, Barnes KM, Emons JA, Newman EI, Nilsson O, Baron J: Depletion of resting zone chondrocytes during growth plate senescence. J Endocrinol 2006;189:2736.

59 Lui JC, Chen W, Barnes KM, Baron J: Changes in gene expression associated with aging commonly originate during juvenile growth. Mech Ageing Dev 2010;131:641-649. 
60 Carani C, Qin K, Simoni M, Faustini-Fustini M, Serpente S, Boyd J, Korach KS, Simpson ER: Effect of testosterone and estradiol in a man with aromatase deficiency. $\mathrm{N}$ Engl J Med 1997;337:91-95.

61 Akiyama H, Chaboissier MC, Martin JF, Schedl A, de Crombrugghe B: The transcription factor Sox 9 has essential roles in successive steps of the chondrocyte differentiation pathway and is required for expression of Sox 5 and Sox6. Genes Dev 2002;16:28132828.

-62 Chrysis D, Nilsson O, Ritzen EM, Savendahl L: Apoptosis is developmentally regulated in rat growth plate. Endocrine 2002;18:271278.

-63 Ahmed YA, Tatarczuch L, Pagel CN, Davies HM, Mirams M, Mackie EJ: Physiological death of hypertrophic chondrocytes. Osteoarthritis Cartilage 2007; 15:575-586.

64 Cohen JJ: Apoptosis. Immunol Today 1993; 14:126-130.

65 Roach HI, Clarke NM: Physiological cell death of chondrocytes in vivo is not confined to apoptosis. New observations on the mammalian growth plate. J Bone Joint Surg $\mathrm{Br}$ 2000;82:601-613.

66 Emons J, Chagin AS, Hultenby K, Zhivotovsky B, Wit JM, Karperien M, Savendahl L: Epiphyseal fusion in the human growth plate does not involve classical apoptosis. Pediatr Res 2009;66:654-659.
67 Roach HI, Clarke NM: 'Cell paralysis' as an intermediate stage in the programmed cell death of epiphyseal chondrocytes during development. J Bone Miner Res 1999;14:13671378.

68 Roach HI, Clarke NM: Physiological cell death of chondrocytes in vivo is not confined to apoptosis. New observations on the mammalian growth plate. J Bone Joint Surg Br 2000;82:601-613.

69 Roach HI, Aigner T, Kouri JB: Chondroptosis: a variant of apoptotic cell death in chondrocytes? Apoptosis 2004;9:265-277.

70 Settembre C, rteaga-Solis E, McKee MD, de PR, Al AQ, Ballabio A, Karsenty G: Proteoglycan desulfation determines the efficiency of chondrocyte autophagy and the extent of FGF signaling during endochondral ossification. Genes Dev 2008;22:2645-2650.

71 Shapiro IM, Adams CS, Freeman T, Srinivas $\mathrm{V}$ : Fate of the hypertrophic chondrocyte: $\mathrm{mi}$ croenvironmental perspectives on apoptosis and survival in the epiphyseal growth plate. Birth Defects Res C Embryo Today 2005;75: 330-339.

72 Roach HI, Aigner T, Kouri JB: Chondroptosis: a variant of apoptotic cell death in chondrocytes? Apoptosis 2004;9:265-277.

73 Moskalewski S, Malejczyk J: Bone formation following intrarenal transplantation of isolated murine chondrocytes: chondrocytebone cell transdifferentiation? Development 1989;107:473-480.
74 Groot CG, Thesingh CW, Wassenaar AM, Scherft JP: Osteoblasts develop from isolated fetal mouse chondrocytes when co-cultured in high density with brain tissue. In Vitro Cell Dev Biol Anim 1994;30A:547-554.

75 Adams CS, Shapiro IM: The fate of the terminally differentiated chondrocyte: evidence for microenvironmental regulation of chondrocyte apoptosis. Crit Rev Oral Biol Med 2002;13:465-473.

76 Horton WA, Dwyer C, Goering R, Dean DC: Immunohistochemistry of types I and II collagen in undecalcified skeletal tissues. J Histochem Cytochem 1983;31:417-425.

77 White JR, Wilsman NJ, Leiferman EM, Noonan KJ: Histomorphometric analysis of an adolescent distal tibial physis prior to growth plate closure. J Child Orthop 2008;2: 315-319.

78 Stewart AJ, Houston B, Farquharson C: Elevated expression of hypoxia inducible factor2alpha in terminally differentiating growth plate chondrocytes. J Cell Physiol 2006;206: 435-440.

79 Scortegagna M, Ding K, Oktay Y, Gaur A, Thurmond F, Yan LJ, Marck BT, Matsumoto AM, Shelton JM, Richardson JA, Bennett MJ Garcia JA: Multiple organ pathology, metabolic abnormalities and impaired homeostasis of reactive oxygen species in Epas1-/mice. Nat Genet 2003;35:331-340. 